Olga Lundysheva ${ }^{1}$

\title{
A Fragment of a Tocharian B Text concerning the Conversion of Uruvilvā-Käśyapa
}

DOI $10.17816 /$ wmo34966

Abstract: This article is a publication of two fragments of a Tocharian B manuscripts kept in the Petrovsky sub-collection of the Serindian Collection of the IOM RAS with a text of Buddhist content related to the conversion of Uruvilvā-Käśyapa. The article provides transliteration and transcription of the text, as well as the provisional translation. Assumptions are made regarding the Sanskrit and Tocharian B literature parallels.

Key words: Tocharian B, Central Asian Buddhism, textology, manuscriptology

Two Tocharian B fragments with shelf numbers SI 2089/1-2 (old number P/66) belong to the Petrovsky collection of the IOM RAS. Supposedly, they were acquired in Kuča region, but the findspot is unknown. Both fragments are written on similar paper and the ductus is similar either. Still, according to the content, one cannot be completely sure that these fragments do belong to the same manuscript. While the content of the second (small) fragment is not identified, the first one is from a text concerned with the conversion of Uruvilvā-Käśyapa.

\section{Material description}

Fragment 1: size ( $\mathrm{h} \mathrm{x} \mathrm{w,} \mathrm{maximal):} 14.8 \times 19.8 \mathrm{~cm}$. The left part of a leaf. The lower and upper edges are visible. Six lines of text are still visible on both sides, and this must also have been the original number of lines of the

\footnotetext{
${ }^{1}$ (C) Lundysheva Olga, Junior Researcher of the Laboratoria Serindica, IOM, RAS (olgavecholga@gmail.com),2020
} 
manuscript. The string hole is preserved. The string hole space is rectangular in shape $(6.5 \times 5.7 \mathrm{~cm})$ and is separated by guidelines. The left margin is present. The margin is separated by a ruler line. Pagination: 94 .

Fragment 2: size ( $\mathrm{hx} \mathrm{w}$, maximal): $6.0 \times 10.0 \mathrm{~cm}$. The middle part of a leaf. Two lines of text are still visible on both sides.

The paper is thick, one-layered. Laid lines are visible (5 in $1 \mathrm{~cm})$. The paper was primed with white paste and ruled. Rule lines are black. Spacing between the lines is about $2.3 \mathrm{~cm}$.

\section{Dating}

The highly calligraphic manner of the writing, ornamental layout of the leaf and several late linguistic forms suggest that the manuscript belongs to the later period of the Tocharian literature.

\section{Metre}

The manuscript contains a verse part inserted into the prose text indicated by the double dots and by the marked word order. The metrical segment wāsko śaișentse lyelyakormem wrocce sü: 1 suggests that the metre was $4 \times 12$ syllables, subdivision $5 / 7$ (more exactly $5 / 4+3$ ) or $4 \times 14$ syllables, subdivision $7 / 7$ (more exactly $4+3+4+3$ ). The name of the metre is unknown.

[ ] uncertain reading

- one unreadable akșara

- unreadable consonantal or vocalic part of an akșara

//I torn edge of a fragment

- dot, punctuation mark

: $\quad$ double dot, punctuation mark (mostly metrical)

a string hole

ś and other underlined consonants represent so-called Fremdzeichen

a $\quad$ so-called Fremdvokal, equivalent to $\ddot{a}$

r、 consonant in virāma position (without dot, mostly with Fremdzeichen consonant) 


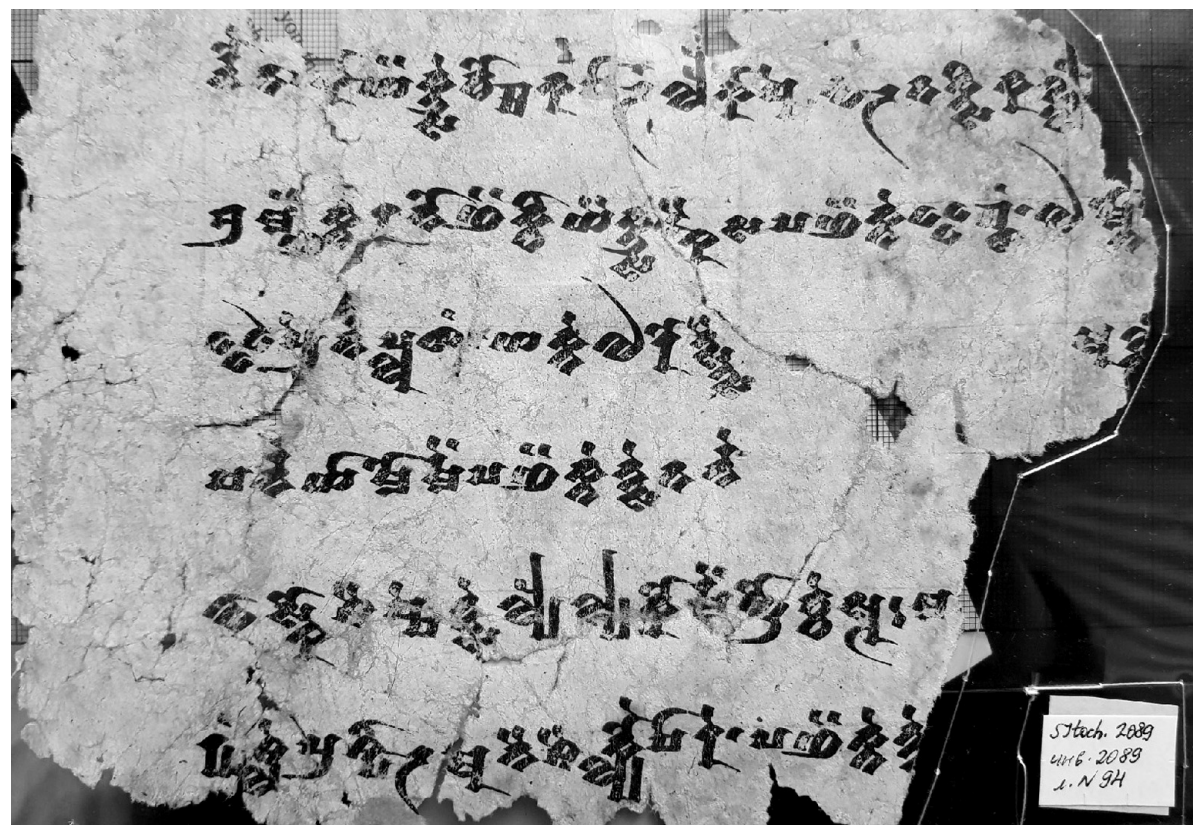

fig. 1: SI 2089/1, recto

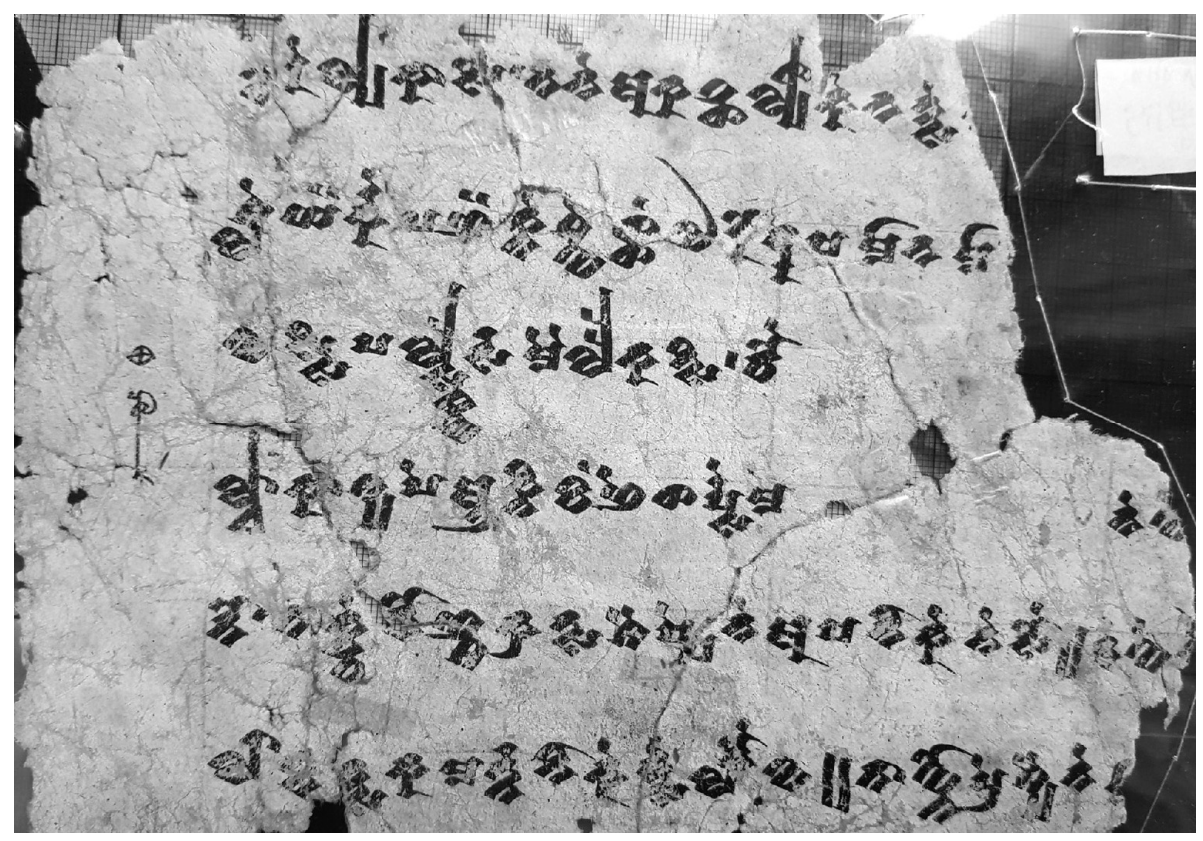

fig. 2: SI 2089/1, verso 


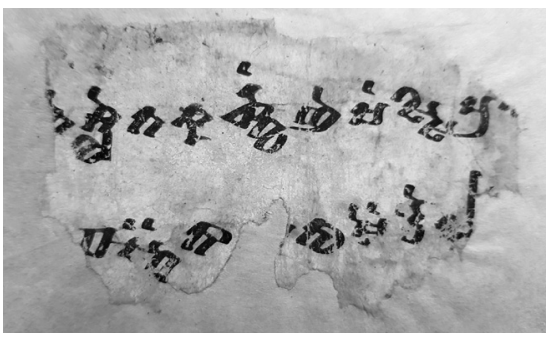

fig. 3: SI 2089/2, side A

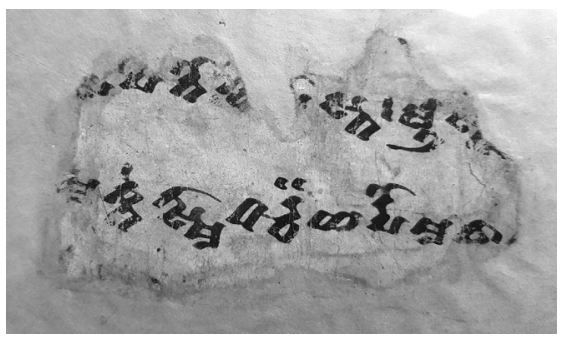

fig. 4: SI 2089/2, side B

\section{Transliteration}

Fragment 1

a1 rnau tākoy ${ }^{a}, k_{u}$ se com kașāar $_{i}^{2}$ laikoșse war taktsi kall[au] //I

a2 bramñäkte rano ñäkcìyai $k_{u} s=$ ankaisa pañäkte ipssam • omto //I

a3 iprern[·] pluṣam • yakte orotstsai : al[le] III

a4 sarne yāmormem pañäktentse tarne $\mathrm{\alpha} / / / \mathrm{I}$

a5 wāsko śaișsentse lyelyakormem wrocce sū : ma /II

a6 ryam śle praśpīr 、 anaiśai klyaușāre • pañäktent[·]e I/I

94

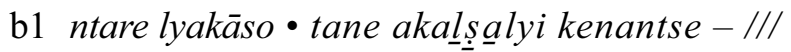

b2 śle yärke pañäkteś weșạm oroccu șamāna mā-I/I

b3 wassi palskw ersamai laikatsi $\bullet$ cau o //I

b4 lvā kāśyape āktikamñe șarpsema o ne w[e] //I

b5 to • ta $k_{u}$ ce no ñśak ra tsa șaișșene așanīke nesau || te we [ñā] ///

b6 r lāntantsa kamarttanīkentse klauwa \| tāw no preśyaine [mā] I/I

\section{Fragment 2}

a1 /// neśle takarșkamñe șamssi pra[t] ] ///

a2 ///pastä $\underline{a}^{3} t \bar{a}-[\bullet]$ tumem cau $l[a] / / /$

b1 $/ / / \cdot \cdot \cdot \cdot$ pito $w^{4}[s \bar{a}]$ sta $: \overline{a s t} \cdot / / /$

b2 /// makte tsmātarc ${ }^{a}$, yarpo makā - ///

${ }^{2}$ As in this manuscript virāma with Fremdzeichen consonant does not include a dot, this dot should be regarded as a punctuation mark. However, syntactically a punctuation mark is not expected here. The end of the sentence should be after tākoy ${ }^{\ddot{a}}$. Still there any marking is absent (may be in order not to add one more dot after the two-dots virama needed after a nonFremdzeichen consonant).

${ }^{3}$ As here a virāma with Fremdzeichen is used, one would expect no dots above the akșara. However, a ligature consists of a non-Fremdzeichen consonant 's" and a Fremdzeichen " $\underline{\text { ' }}$. So, maybe it was "s" which effected the two-dots virāma.

${ }^{4}$ A vowel, supposedly the Fremdvokal, is inserted for metrical reasons. 


\section{Assumed parallels:}

The text is supposed to contain a passage of a story about the conversion of the ascetic Uruvilvā-Käśyapa with his brothers and disciples, who were followers of fire-worship, to Buddhism. Buddha had to make a great number of miracles to convince them. The story is known from two sources in Indian languages: ${ }^{5}$ the Mahāvagga ${ }^{6}$ I, $15-23^{7}$ and the Mahāvastu ${ }^{8}$ III, 428-430. ${ }^{9}$ The stories vary considerably. ${ }^{10}$ Though they match on substantive items, the miracles mentioned in the Mahāvastu UruvilvāKāśyapaNadīKāśyapaGayā Käśyapa-jātaka do not coincide (except three) with those in the corresponding Mahāvagga episode.

The principal structure of both variants is similar. Buddha shows a miracle, and Uruvilvā-Käśyapa is appalled at the evidence of his miraculous powers. However, he thinks that his magic and status are greater. There is a refrain that recurs each time this situation is replicated. In the Sanskrit version it is marked by the phrase: yam aham punar maharddhikataro, ${ }^{11}$ vayam punar maharddhikatarā: ${ }^{12}$ "Nevertheless it's me [who is the possessor] of the greatest magical powers", in the Pāli version by the phrase: na tu eva ca kho arahā yathā aham ti: "But, however, indeed not surely [he is an] arhant like me". Thus, one can observe that while in the Sanskrit story Uruvilvā-Käśyapa underlines the fact that his magic powers are more powerful, in the Pāli story he focuses on his arhatship, meaning that his stage of emancipation is higher.

For reasons that will become clear later, three ${ }^{13}$ of those miracles from the Mahāvagga, which are absent in the Mahāvastu, are list here. The first miracle: Buddha triumphs over a Nāga king conquering the fire of the Nāga

\footnotetext{
${ }^{5}$ As it is quite unlikely that the primary source for a Tocharian text could be a text in a non-Indian language, the other (Tibetan, Chinese etc.) versions are not mentioned.

${ }^{6}$ Mahàvagga is the first volume of Khandhaka, the second book of the Theravadin Vinaya Pitaka. The first chapter is called the great chapter - Mahākhandhaka.

${ }^{7}$ Pāli text edition according to BiBliotheCA PolyglotTA.

${ }^{8}$ Mahāvastu, a text of the Mahāsāmenghika-Lokottaravāda school of Early Buddhism, which is regarded as a collection of the avadanna genre related to the Vinaya. For details see TOURNIER 2012.

${ }^{9}$ Sanskrit text edition according to MARCINIAK 2019.

${ }^{10}$ About differences see WINDISCH 1909, 497-499.

${ }^{11}$ MARCINIAK 2019, 550.

${ }^{12}$ MARCINIAK 2019, 552.

${ }^{13}$ For the description of all the miracles from the Mahāvagga see TALIM 2002-2203, 249263.
} 
king with his own fire. The second miracle: four Mahārāja deities, in the shape of pillars of fire, come to hear the Buddha's sermon. The sixth miracle needs to be quoted almost entirely. ${ }^{14}$ "At that time, the Blessed One had rags taken from a dust heap (of which he was going to make himself a dress). Now the Blessed One thought: 'Where shall I wash these rags?' Then Sakka the king of the devas, understanding in his mind the thought which had arisen in the mind of the Blessed One, dug a tank with his own hand, and said to the Blessed One: 'Lord, might the Blessed One wash the rags here.' And the Blessed One thought: 'What shall I rub the rags upon?' [1] Then Sakka the king of the devas, understanding in his mind the thought which had arisen in the mind of the Blessed One, put there a great stone and said: 'Lord, might the Blessed One rob the rags upon this stone.' And the Blessed One thought: 'What shall I take hold of when going up (from the tank)?' Then a deity that resided in a Kakudha tree, understanding in his mind the thought which had arisen in the mind of the Blessed One, bent down a branch and said: 'Lord, might the Blessed One take hold of this branch when going up (from the tank).' And the Blessed One thought: 'What shall I lay the rags upon (in order to dry them)?' [2] Then Sakka the king of the devas, understanding in his mind the thought which had arisen in the mind of the Blessed One, put there a great stone and said: 'Lord, might the Blessed One lay the rags upon this stone.' And when that night had elapsed, the Gatila Uruvelâ Kassapa went to the place where the Blessed One was; having approached him, he said to the Blessed One: 'It is time, great Samana, the meal is ready. [3] What is this, great Samana? Formerly there was here no tank, and now here is this tank. Formerly no stone was put here; by whom has this stone been put here? Formerly this Kakudha tree did not bend down its branch, and now this branch is bent down.' 'I had rags, Kassapa, taken from a dust heap; and I thought, Kassapa: "Where shall I wash these rags?" Then, Kassapa, Sakka the king of the devas, understanding in his mind the thought which had arisen in my mind, dug a tank with his hand and said to me: "Lord, might the Blessed One wash the rags here." Thus, this tank has been dug by the hand of a non-human being. 'And I thought, Kassapa: "What shall I rub the rags upon?" Then, Kassapa, Sakka, ... [4] Thus this stone has been put here by a non-human being. 'And I thought, Kassapa: "What shall I take hold of when going up (from the tank)?" Then, Kassapa, a deity,... . Thus, this Kakudha tree has served me as a hold for my hand.

\footnotetext{
${ }^{14}$ Translation according to PĀLI VINAYA 1965.
} 
'And I thought, Kassapa: "Where shall I lay the rags upon (in order to dry them)?" Then, Kassapa, Sakka,... [5] Thus this stone has been put here by a non-human being.' Then the Gatila Uruvelâ Kassapa thought: 'Truly the great Samana possesses high magical powers and great faculties since Sakka the king of the devas does service to him. He is not, however, holy like me."'

In SI 2089/1 b5 one can see the phrase ta $k_{u} c e$ no ñśak ra tsa śaișsene așanike nesau "anyway, even though, (he is not) the worthy [one] amongst people ${ }^{15}$ just like I am", which is close in meaning with the Pāli phrase na tu eva ca kho arahā yatha aham "but, however, indeed not surely (he is an) arhant like me". The Tocharian word așanike "the worthy [one] is a standard equivalent of the Sanskrit term arhat or Pâli arahant (nom. sg. arahā). Though except for this example the Tocharian and Pāli texts do not correspond phrase by phrase, it is clear that the Tocharian version tells the same story as the Pāli one. Note SI 2089/1 a1 $k_{u}$ se com kaṣār laikoṣse war taktsi "that robe, [in] gain to wash (lit. to touch the water for washing)", SI 2089/1 b3 wassi palskw ersamai laikatsi "I got the thought to wash clothes". The Tocharian text is elaborated and expanded by additional details, which could be added by a Tocharian author or could be translated from a Sanskrit original whose text has not been preserved.

\section{Transcription}

Fragment 1

a1 (pe)rnau tākoy $k_{l}$ se com kașār laikoșșe war taktsi kallau III

a2 bramñäkte rano ñäkcīyai $k_{u} s=$ ankkaisa pañäkte ipṣäm • om no //I

a3 iprern(e) plusäm • yakte orotstsai alle (k) /II

a4 (añcalī) șarne yāmormem pañäktentse tarne III

a5 wāsko śaișsentse lyelyakormem wrocce sū : ma III

a6 (plo)ryam śle praśpīr anaiśai klyaușāre • pañäktent(s)e I/I

leaf number 94

b1 (wä)ntare lyakāso - tane akalṣälyi kenantse - //I

b2 śle yärke pañäkteś weșänm oroccu șamāna mā - III

b3 wassi palskw ersamai laikatsi $\bullet$ cau //I

b4 (uruvi)lvā kāśyape āktikämñe șärpsemane we(șsem) I/I

b5 to $\bullet$ ta $k_{u}$ ce no ñśak ra tsa śaiș̣ene aṣanīke nesau || te weña ///

b6 r lāntantsa kamarttanīkentse klauwa || tāw no preśyaine mā /II

${ }^{15}$ Or "in the world". 
Fragment 2

a1 /// eneśle takarșkämñe șamssi prat $\cdot / / /$

a2 /// päst tāa $(\mathrm{ka}) \cdot$ tumem cau la ///

b1 /// (t)s(e) pito w(ä)sāsta : āst t $\cdot / / /$

b2 /// makte tsmātärc yarpo makā - ///

\section{Comments}

Fragment 1

a1 pernau - possibly a later form of perne ${ }_{u}:{ }^{16}$ adjective, nom. sg. masc, "worthy, glorious". It could be either the subject or the predicate of the verb tākoy: "A Glorious (one) would be" or "would be glorious".

al tākoy - 3sg. active optative from nes- a verb of existance or a copula. ${ }^{17}$

a1 $k_{u} s e-$ nom. sg. masc., ${ }^{18}$ of the relative pronoun "who, whoever, which".

a1 com - obl. sg. masc., of the demonstrative pronoun $\operatorname{sam}(p)$ "that (one)". ${ }^{19}$

a1 kașār - noun, obl. sg., "robes", saffron-colored monk's garb. ${ }^{20}$

a1 laikossse - adjective, nom./obl. sg. masc., should be a derivative of the word laiko "bath, washing". ${ }^{21}$

a1 war - noun, nom./obl. sg., "water"; ${ }^{22}$ here probably a direct object of a verb täk- "to touch" 23 in the form of the infinitive taktsi.

a1 kallau - noun, nom./obl. sg. masc., "gain, profit", ${ }^{24}$ it is possible that there was a locative casal ending: kallaune.

a2 bramñäkte - noun, nom./obl. sg. masc., "(the god) Brahma". 25

a2 rano - conj., with adjectives "however". ${ }^{26}$

a2 ñ̈̈kcìyai - adjective, obl. sg. fem., "divine"; maybe for a word maiyya ${ }^{27}$ obl. sg. fem., "power".

\footnotetext{
${ }^{16}$ ADAMS 2013, 426.

17 ADAMs 2013, 365-366.

${ }^{18}$ Used with all genders and both numbers according to ADAMS 2013, 200.

${ }^{19}$ ADAMS 2013, 739.

${ }^{20}$ ADAMS 2013, 157.

21 ADAMS 2013, 610 .

22 AdAMs 2013, 627.

${ }^{23}$ ADAMS 2013, 305.

${ }^{24}$ ADAMs 2013, 156.

${ }^{25}$ ADAMS 2013, 466.

${ }^{26}$ ADAMS 2013, 571.

27 ADAMs 2013, 508.
} 
a2 ankkaisa - adverb, "reverse"; one would expect the spelling ankkai\{n\}sa.

a2 ipṣäm - 3sg. caus. active present from yäp- "let enter"; one would expect the spelling yapäșsäm "lets enter".

a2 om no - "there then".

a3 iprene - noun, loc. sg. masc., of iprer "sky, air"; 28 one would expect the spelling $\bar{\imath} p r e\{r\}$ ne.

a3 pluṣäm - 3sg. active present from plu- "fly". ${ }^{29}$

a3 yakte - adjective, nom./obl. sg./pl. masc./fem. "small, little". 30

a3 orotstsai - adjective, obl. sg. masc., "great, big" or noun "adult". ${ }^{31}$

a3 allek - adjective, nom. sg. masc. "other, another". ${ }^{32}$

a4 (añcalī) șarne yāmormem - absolutive in -ormem from añcalī șarne yām- "to fold hands", as in THT 92, a5: añcalī șarne yāmu aranemi weșäm "with folded hands Aranemi speaks"."

a4 tarne - noun, nom./obl. sg., "crown of the head". ${ }^{34}$

a5 wāsko - nom./obl. sg. masc., a nominal derivative from wāsk- "to move". "movement, stir". 36

a5 śaișsentse - noun, gen. sg. masc., of śaișșe "world, people". ${ }^{37}$

a5 lyelyakormem - absolutive in -ormem from läk- "to see, look". ${ }^{38}$

a5 wrocce - adjective, obl. sg. masc. "great"." 99

a5 $s \bar{u}-$ nom. sg. masc., of the demonstrative pronoun $s u$, the usual anaforic pronoun of Toch B. ${ }^{40}$

a6 (plo)ryam - noun, acc. pl. "a musical instrument".

a6 śle - "(together) with".

a6 praśpir - according to the context, it should be a musical instrument. Compare IOL Toch 66 a3 praśpir klyau $\cdot e-.^{43}$

${ }^{28}$ ADAMS 2013, 70.

${ }^{29}$ ADAMS 2013, 462.

${ }^{30}$ ADAMS 2013, 535. Here it stands only for compositas and in forms yäkte or yekte.

${ }^{31}$ ADAMS 2013, 127.

${ }^{32}$ ADAMS 2013, 30

${ }^{33}$ Transcription and translation from CEToM.

${ }^{34}$ ADAMS 2013, 298.

${ }^{35}$ ADAMS 2013, 639.

${ }^{36}$ ADAMS 2013, 640.

${ }^{37}$ ADAMS 2013, 696.

${ }^{38}$ ADAMS 2013, 596.

${ }^{39}$ ADAMS 2013, 127.

${ }^{40}$ ADAMS 2013, 758.

${ }^{41}$ ADAMS 2013, 463.

${ }^{42}$ ADAMS 2013, 680.

${ }^{43}$ Transcription from CEToM. 
a6 anaiśai - adverb, "carefully, clearly". 44

a6 klyaușāre - 3pl. active preterite from klyaus- "to hear, listen to".

a6 pañäktentse - noun, gen. sg., "buddha". 45

b1 wäntare - noun, nom./obl. sg., "thing, affair, matter". 46

b1 lyakāso - 2pl. active preterite from läk- "to see, look". 47

b1 tane - adverb, "here, there". 48

b1 akalsälyi - noun, nom. pl., "pupil, scholar". ${ }^{49}$ It also could be a voc. pl. form, however, here the sentence starting with tane akalsälyi is likely to be the beginning of the text following the direct speech of the previous sentence and therefore the case is nominative

b1 kenantse - noun, gen. sg., "earth, ground; base, place". 50

b2 yärke - noun, obl. sg., "deference, honour" 51 One would expect yarke, however, as it is a part of a compound with śle, stressed /ä/, spelled as $<\mathrm{a}>$ becomes unstressed, being spelled as $<\mathrm{a}>$.

b2 pañäkteś - noun, dat. sg., "buddha". 52

b2 oroccu - adjective, voc. sg. masc., "great". 53

b2 șamāna - noun, voc. sg., "monk". 54 Possibly, a first registered occurrence of the singular vocative of this word.

b3 wassi - noun, nom./obl. sg., "clothing, garment", 55

b3 palskw ersamai — a sandhi of palsko, noun, nom./obl. sg. "thought", 56 and ersamai, $1 \mathrm{sg}$. middle, preterit from er- "evoke, produce". 57

b3 laikatsi — infinitive from lik- "wash". 58

b3 cau - obl. sg. masc., of the demonstrative pronoun $s u$, the usual anaphoric pronoun of Toch $\mathrm{B}^{59}$

\footnotetext{
${ }^{44}$ ADAMS 2013, 14.

${ }^{45}$ AdAMs 2013, 375.

${ }^{46}$ ADAMS 2013, 643.

${ }^{47}$ ADAMS 2013, 596.

${ }^{48}$ ADAMS 2013, 295.

49 ADAMS 2013, 2.

${ }^{50}$ ADAMS 2013, 205.

${ }^{51}$ ADAMS 2013, 521.

${ }^{52}$ ADAMS 2013, 375.

${ }^{53}$ ADAMS 2013, 127.

${ }^{54}$ ADAMS 2013, 711.

${ }^{55}$ ADAMS 2013, 635.

${ }^{56}$ ADAMS 2013, 385.

${ }^{57}$ ADAMs 2013, 98.

${ }^{58}$ ADAMS 2013, 600.

${ }^{59}$ ADAMs 2013, 758.
} 
b4 urbilvā käśyape - [urbi]lvā is reconstructed according to the THT 1575. g., line b6. ${ }^{60}$

b4 āktikämñe - noun, nom./obl. sg., "wonder, miracle". ${ }^{61}$

b4 șärpsemane - m-participle from șärp- "explain to, indicate". ${ }^{62}$

b4 weșsem - 3sg. active present from we- "speak, say". ${ }^{3}$

b5 $t a-$ particle, "this, here, now". ${ }^{64}$

b5 $k_{u}$ ce-conj., "because, (so) that, since". ${ }^{65}$

b5 ñśak - "precisely me", from ñäś, pronoun, "I, me", ${ }^{66}$ combined with $k \ddot{a}$, emphasising particle, "only". ${ }^{67}$

. no - conj., "but, however". ${ }^{68}$

b5 ra tsa - "any, anyway, whatsoever". ${ }^{69}$

b5 śaișsene - noun, loc. sg. masc., of śaișse "world, people". ${ }^{70}$

b5 așan̄ke - noun, nom. sg., "worthy one", ${ }^{71}$ a semantical equivalent of arhänte "arhat". ${ }^{72}$

b5 nesau - 1sg. active, present from nes- a verb of existence or a copula. $^{73}$

b5 te - nom./obl. sg. masc., of the demonstrative pronoun se, the usual proximal pronoun of Toch B. ${ }^{74}$

b5 weñā- - 3sg, active preterite from we- "to speak" "75 with a pronoun suffix such as weñā-ne, weñā-me, etc.

b6 lāntantsa - noun., perl. pl., of walo "king", "among the kings"??

b6 kamarttanīkentse - noun, gen. sg., of kamartīke "ruler".

b6 klauwa - preterite participle, nom, pl. fem. from käl- "bring". 76 Possibly, a first registered occurrence of the form.

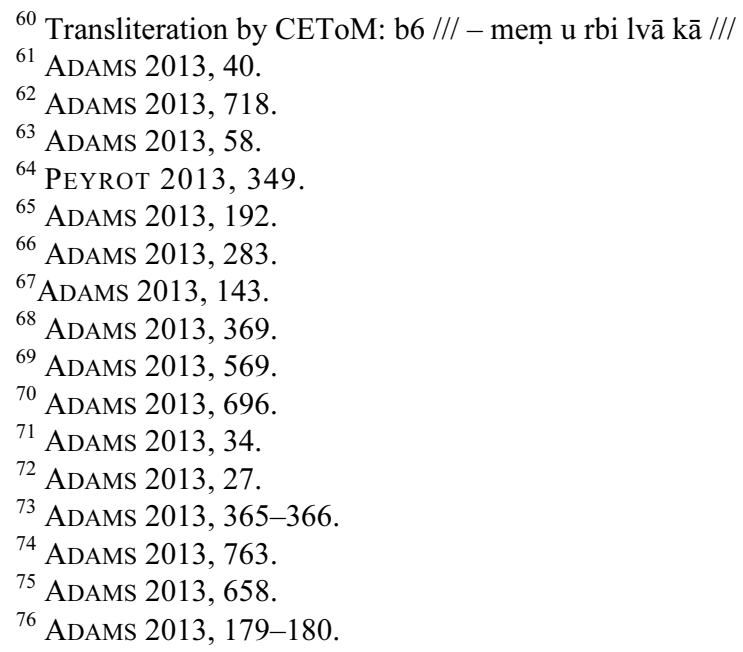


b6 tâw - obl. sg. fem. of the demonstrative pronoun $s u,{ }^{77}$ the usual anaforic pronoun of Toch B. ${ }^{78}$

b6 preśyaine — noun, loc. sg. fem., "time". 79

\section{Fragment 2}

a1 eneśle - postposition, "like". 80

a1 taka - adverb, "then, certainly". ${ }^{81}$

al rșkämñne — adj., nom./obl. sg. masc., "pertaining to a ṛși"; one would expect rșākäññe. ${ }^{82}$

a1 șaṃssi — infinitive from șäms- "to count (as)". ${ }^{83}$

a2 päst - particle, "away, back". 84

a2 tāka - $3 \mathrm{sg}$, active preterit from nes- a verb of existence or a copula. ${ }^{85}$

a2 tumem - adverb, "then, thereupon". 86

b1 -tse pito — noun, nom./obl. sg., "price" 87 with a genitive form of a noun.

b1 $w(\ddot{a}) s \bar{a} s t a-2 \mathrm{sg}$, active preterit from wäs- "to give". 88

b1 āst $t$. — from āyo "bone", nom. obl. pl or any casal form from the obl. plural.

b2 makte - pronoun, nom. sg., "-self". 89

b2 tsmātär-c - 3sg, middle subjunctive from tsäm- "grow [in size or number]" ${ }^{\prime 90}$ with a pronoun suffix (2sg.).

b2 yarpo — noun, nom./obl. sg., "merit".

b2 makā - adjective, "many. much"; as a part of a compound, for example makā-ykne "in manifold ways". 92

\footnotetext{
${ }^{77}$ ADAMS 2013, 758.

${ }^{78}$ ADAMS 2013, 758.

${ }^{79}$ ADAMS 2013, 454.

${ }^{80}$ ADAMS 2013, 90.

${ }^{81}$ ADAMS 2013, 292.

${ }^{82}$ ADAMS 2013, 589.

${ }^{83}$ ADAMS 2013, 715.

${ }^{84}$ ADAMS 2013, 408.

${ }^{85}$ ADAMS 2013, 365-366.

${ }^{86}$ ADAMS 2013, 319.

${ }^{87}$ ADAMS 2013, 412.

${ }^{88}$ ADAMS 2013, 649.

${ }^{89}$ ADAMS 2013, 469.

${ }^{90}$ ADAMS 2013, 804.

${ }^{91}$ ADAMS 2013, 522.

${ }^{92}$ ADAMS 2013, 479.
} 


\section{Tentative translation}

Fragment 1

a1 a Glorious (one) would be. ${ }^{93}$ Who [...] that robe [in] gain to wash (lit. to touch the water for washing).$^{94}$

a2 god Brahma, too, [exerted] divine [power?], which let the Buddha enter back (from the tank?); ${ }^{95}$ there then ...

a3 flies in the sky. Another [one] (nom.) big and small (acc.) ...

a4 having [his] hands folded, (he honoured?) the top of the head of Buddha ...

a5 having seen the great stir [among] people, he ...

a6 they clearly heard flutes and praśpir; ... of the Buddha ...

94

b1 the matter you (pl.) have seen. Here the disciples ... of the earth ...

b2 with deference [he] says to the Buddha: "Oh great monk, ...

b3 I got the idea to wash clothes. That ...

b4 Uruvilvā Kāśyapa, indicating the miracle, says: ...

b5 anyway, it is precisely me [who is] the worthy [one] in the world. $\mathrm{He}$ said this to ...

b6 they (f.) were brought by the ruler over the kings. However, at that time

${ }^{93}$ Or "would be glorious".

${ }^{94}$ This text is exceedingly difficult for understanding and translation not only due to the the punctuation confusion mentioned above but also because the phrase is broken off in the mid-sentence. One can think of several translational possibilities. For example, Michaël Peyrot, giving me a kind consultation concerning this tricky fragment, suggested a few samples such as

1) "What (is) the profit to touch that garment [and] the bathing water?" (meaning "wash the garment with bathing water").

2) "Who (has ... placed here??) ... for the profit (+ loc.) of touching that garment and the bathing water".

3) "If I get to touch that garment and the bathing water..." (with $k_{u} s e$ in the sense of "if"?? and kallau as 1 sg.sbj. of kälpa-).

4) The sentence contains a translated Sanskrit compound "that-garment-washing-watertouch-..." or something like that.

Anyway, as there is not enough material to translate this part of the text with a high degree of certainty I've decided to base the translation on the supposed Sanskrit parallel referring to the situation when Buddha came to the tank to wash his robe made of rags.

${ }^{95}$ Supposing from the context. 


\section{Fragment 2}

a1 ... like faith [is?] to count ...

a2 ... is over. Then that (acc.) ...

b1 ... you gave the price of .... Bones ...

b2 ... self will grow for you. In many(fold ways) ...

\section{Notes:}

There is one more Tocharian manuscript which appears to contain the description of the first or maybe of the second miracle. This is IOL Toch $86 .{ }^{96}$ SI 2089/1 b5 ta $k_{u}$ ce no ñśak ra tsa śaișșene așanīke nesau \|te weñā /// corresponds to IOL Toch 86 b5 -șanike nesau || te we(we)ño(rmem) I/I, being the same refrain indicating the story. Here also such words as ysintse, gen.sg. of "night", pwārntse gen.sg. of "fire" and swañcaișsai "radiant" are mentioned, which could refer either to the first or to the second miracle, or to both of them consequently. ${ }^{97}$ Possible. but then you have to mention that you cannot treat this fragment in more detail here.

${ }^{96}$ Published in PeYrot 2007.

${ }^{97}$ Translation according to PĀLI VINAYA 1965.

"Then the Blessed One entered the room where the fire was kept, made himself a couch of grass, and sat down cross-legged, keeping the body erect and surrounding himself with watchfulness of mind. And the Nāga saw that the Blessed One had entered; when he saw that, he became annoyed, and irritated, and sent forth a cloud of smoke. Then the Blessed One thought: 'What if I were to leave intact the skin, and hide, and flesh, and ligaments, and bones, and marrow of this Nāga; but were to conquer the fire, which he will send forth, by my fire.' And the Blessed One effected the appropriate exercise of miraculous power and sent forth a cloud of smoke. Then the Nāga, who could not master his rage, sent forth flames. And the Blessed One, converting his body into fire, sent forth flames. When they both shone forth with their flames, the fire room looked as if it were burning and blazing, as if it were all in flames. And the Gatilas, surrounding the fire room, said: 'Truly, the countenance of the great Samana is beautiful, but the Nāga will do harm to him.' That night having elapsed, the Blessed One, leaving intact the skin and hide and flesh and ligaments and bones and marrow of that Nāga, and conquering the Nāga's fire by his fire, threw him into his alms-bowl, and showed him to the Gatila Uruvelā Kassapa (saying), 'Here you see the Nāga, Kassapa; his fire has been conquered by my fire.' Then the Gatila Uruvelā Kassapa thought: 'Truly the great Samana possesses high magical powers and great faculties, in that he is able to conquer by his fire the fire of that savage Nāga king, who is possessed of magical power, that dreadfully venomous serpent. He is not, however, holy (arahā) as I am.' ...End of the first Wonder. And the Blessed One resided in a certain grove near the hermitage of the Gatila Uruvelā Kassapa. And on a beautiful night the four Mahārājas, filling the whole grove with light by the brilliancy of their complexion, went to the place where the Blessed One was; having approached him and respectfully saluted the Blessed One, they stood in the four directions like great firebrands. And when that night had elapsed, the Gatila Uruvelā 
Though the refrain clearly indicates the story as the Uruvilvā-Käśyapa jātaka contained in the Pāli Mahāvagga, here is however some uncertainty concerning the SI 2089/1 fragment because the text is too fragmentary. Then, it is possible that the complete manuscript contained the successive telling of several jâtakas in very abridged form (a type of text which is known otherwise). And among them, it contained the jātaka of Uruvilvā-Käśyapa. Another possibility is that a miracle from the Uruvilvā-Käśyapa story (or the whole story itself) was mentioned for illustrative purposes in a text of unknown content.

\section{References}

ADAms, Douglas Q. 2013: A dictionary of Tocharian B. Revised and greatly enlarged. 2 vol. Amsterdam: Rodopi. (Leiden studies in Indo-European, 10).

MarciniaK, Katarzyna 1965: The Mahāvastu. A New Edition. Vol. III. Tokyo: The International Research Institute for Advanced Buddhology, Soka University.

PĀLI VINAYA 1965: Vinaya Texts Translated from the Pāli by T.W. Rhys Davids and Hermann Oldenberg. Pt. 1. The Pātimokkha. The Māhavagga, I-IV. Delhi: Motilal Banarsidass.

PeYrot, Michaël 2013: The Tocharian Subjunctive: A Study in Syntax and Verbal Stem Formation. Leiden, Boston: Brill. (Brill's Studies in Indo-European Languages \& Linguistics, 8).

TALIM, Meena 2002-2003: Buddha and Miracles. Bulletin of the Deccan College PostGraduate and Research Institute, 62/63, 249-263.

TOURNIER, Vincent 2012: The Mahāvastu and the Vinayapitaka of the MahāsānghikaLokottaravādin. In: Annual Report of The International Research Institute for Advanced Buddhology at Soka University for the Academic Year 2011 [= ARIRIAB], vol. XV, March, 87-104.

WiNDISCH, Ernst 1909: Die Komposition des Mahāvastu ein Beitrag zur Quellenkunde des Buddhismus. Leipzig: Teubner, 497-499.

\section{Online resourses:}

BiBLIOTHECA PoLYGLOTTA https://www2.hf.uio.no/polyglotta/index.php?page=fulltext\&view= fulltext\&vid $=820 \& \mathrm{cid}=623569 \& \mathrm{mid}=1407820 \&$ level $=1$

CEToM https://www.univie.ac.at/tocharian/

PEYROT Michaël 2007: An edition of the Tocharian fragments IOL Toch 1 - IOL Toch 822 in the India Office Library.

International Dunhuang Project. http://idp.bl.uk/database/oo_cat.a4d?shortref=Peyrot_2007.

Kassapa went to the place where the Blessed One was; having approached him, he said to the Blessed One: 'It is time, great Samana, the meal is ready. Who were they, great Samana, who came, this beautiful night, filling the whole grove with light by the brilliancy of their complexion, to the place where you were, and having approached you and respectfully saluted you, stood in the four directions like great firebrands?' 'They were the four Mahārājas, Kassapa, who came to me in order to hear my preaching.' Then the Gatila Uruvelā Kassapa thought: 'Truly the great Samana possesses high magical powers and great faculties, since even the four Mahārāgas come to hear his preaching. He is not, however, holy like me.' 